\title{
Xenopus, a Model to Study Wound Healing and Regeneration: Experimental Approaches
}

\author{
Paula G. Slater, Miriam Palacios, and Juan Larraín ${ }^{1}$ \\ Center for Aging and Regeneration, Facultad de Ciencias Biológicas, P. Universidad Católica de Chile, \\ Santiago de Chile, Chile 7820436
}

\begin{abstract}
Xenopus has been widely used as a model organism to study wound healing and regeneration. During early development and at tadpole stages, Xenopus is a quick healer and is able to regenerate multiple complex organs-abilities that decrease with the progression of metamorphosis. This unique capacity leads us to question which mechanisms allow and direct regeneration at stages before the beginning of metamorphosis and which ones are responsible for the loss of regenerative capacities during later stages. Xenopus is an ideal model to study regeneration and has contributed to the understanding of morphological, cellular, and molecular mechanisms involved in these processes. Nevertheless, there is still much to learn. Here we provide an overview on using Xenopus as a model organism to study regeneration and introduce protocols that can be used for studying wound healing and regeneration at multiple levels, thus enhancing our understanding of these phenomena.
\end{abstract}

Understanding how regeneration processes occur has been an ancient question. Considering Stedman's Medical Dictionary definition of regeneration, "reproduction or reconstitution of a lost or injured part," both the study of organ regeneration per se and wound healing are crucial to understand the cellular, molecular, and physiological mechanisms underlying regeneration. This knowledge can then be used in the pursuit of treatments for different diseases, wounds, or injuries. Herein we recapitulate the advantages of using Xenopus as a model organism to study wound healing and regeneration and highlight different experimental approaches and methods to study such processes.

Many animal models have been historically used to study regeneration, from nonmammals to mammals, each of them presenting specific advantages and disadvantages (Table 1). Xenopus has been positioned as an ideal model. To start, they can be induced to lay hundreds to thousands of eggs (Cline and Kelly 2012), and their maintenance and breeding is simple and of low cost (Sive et al. 2000; Edwards-Faret et al. 2017), leading to experiments with large sampling and high statistical power. Additionally, performing surgeries and manipulating their embryos is easy because of their size and external development; likewise, they can resist and overcome surgeries of different complexities with simple surgery care (Harland and Grainger 2011). These characteristics, in addition to a well-annotated genome (Hellsten et al. 2010; Session et al. 2016), make Xenopus an outstanding animal model to perform high-throughput experiments, such as RNA sequencing and proteomics (Amin et al. 2014;

${ }^{1}$ Correspondence: jlarrain@bio.puc.cl

From the Xenopus collection, edited by Hazel L. Sive.

(C) 2021 Cold Spring Harbor Laboratory Press

Cite this introduction as Cold Spring Harb Protoc; doi:10.1101/pdb.top100966 
P.G. Slater et al.

TABLE 1. Comparison of some model organisms widely used for regeneration studies

\begin{tabular}{|c|c|c|c|}
\hline $\begin{array}{l}\text { Model } \\
\text { organism }\end{array}$ & Advantages & Disadvantages & References \\
\hline Xenopus & $\begin{array}{l}\text { Regenerative and nonregenerative stages } \\
\text { Large offspring } \\
\text { External development } \\
\text { Genome available } \\
\text { Molecular and genetic techniques } \\
\text { Transgenic lines available } \\
\text { High synteny with mammals }\end{array}$ & $\begin{array}{l}\text { Fewer antibodies available } \\
\text { Injuries not closely analogous to those in } \\
\text { mammals }\end{array}$ & $\begin{array}{l}\text { Session et al. 2016; Ishibashi et al. } \\
\text { 2008; Hellsten et al. 2010; } \\
\text { Edwards-Faret et al. 2017; Slack } \\
\text { et al. 2004; James-Zorn et al. } \\
\text { 2015; Phipps et al. } 2020\end{array}$ \\
\hline Axolotl & $\begin{array}{l}\text { Excellent regenerative capacities } \\
\text { Large offspring } \\
\text { External development } \\
\text { Genome available } \\
\text { Molecular and genetic techniques } \\
\text { High synteny with mammals }\end{array}$ & $\begin{array}{l}\text { Only regenerative stages (does not allow } \\
\text { comparison with nonregenerative stages) } \\
\text { Fewer antibodies available } \\
\text { Improved annotation and genomic assembly are } \\
\text { needed } \\
\text { More extensive transgenic line repository is } \\
\text { needed. } \\
\text { Injuries not closely analogous to those in } \\
\text { mammals }\end{array}$ & $\begin{array}{l}\text { Joven et al. 2019; Joven and Simon } \\
\text { 2018; Gerber et al. 2018; } \\
\text { Nowoshilow et al. 2018; Smith } \\
\text { et al. 2019; Khattak et al. } 2014\end{array}$ \\
\hline Zebrafish & $\begin{array}{l}\text { Excellent regenerative capacities } \\
\text { Large offspring } \\
\text { External development } \\
\text { Genetics } \\
\text { Genome available } \\
\text { Molecular and genetic techniques } \\
\text { Extensive transgenic lines available }\end{array}$ & $\begin{array}{l}\text { Only regenerative stages (does not allow } \\
\text { comparison with nonregenerative stages) } \\
\text { Fewer antibodies available } \\
\text { Injuries not closely analogous to those in } \\
\text { mammals } \\
\text { Evolutionarily further from mammals }\end{array}$ & $\begin{array}{l}\text { Azevedo et al. 2011; Itou et al. } \\
\text { 2012; Marques et al. 2019; } \\
\text { Varshney et al. 2015; Farah et al. } \\
2016\end{array}$ \\
\hline Spiny mouse & $\begin{array}{l}\text { Mammal } \\
\text { Expectedly high protein homology with } \\
\text { Mus musculus (many antibodies } \\
\text { available) } \\
\text { Genetic information available }\end{array}$ & $\begin{array}{l}\text { Only regenerative stages (does not allow } \\
\text { comparison with nonregenerative stages) } \\
\text { Lack of an annotated genome } \\
\text { Fewer tools and techniques (relatively new model) } \\
\text { Small offspring, long gestation } \\
\text { More complex maintenance and postsurgery care }\end{array}$ & $\begin{array}{l}\text { Gawriluk et al. 2019; Gawriluk } \\
\text { et al. 2016; Haughton et al. 2016; } \\
\text { Maden and Varholick 2020; } \\
\text { Brant et al. 2019; Seifert et al. } \\
2012\end{array}$ \\
\hline
\end{tabular}

Collart et al. 2014; Lee-Liu et al. 2014, 2018; Sun et al. 2014; Peshkin et al. 2015). Furthermore, transgenic lines can be generated in large numbers and at low cost (Ishibashi et al. 2008). Techniques using transcription activator-like effective endonucleases (TALENs) and clustered regularly interspaced short palindromic repeat (CRISPR)-Cas9 (Ken-ichi et al. 2013; Guo et al. 2014; Sakane et al. 2014; Nakajima and Yaoita 2015) or injection or electroporation of DNA, mRNA, or morpholinos (Eide et al. 2000; Gómez et al. 2003; Bestman et al. 2006; Blum et al. 2015) are effective in elucidating gene functions. Even though Xenopus laevis has a relatively long generation time (7-12 mo) and an allotetraploid genome, making genetic experiments harder to perform as a result of more complex genome organization and gene content, the sister species Xenopus tropicalis is an alternative for genetics experimentation because of its diploid genome and shorter generation time (3-4 mo). There is extreme similarity between both species, which allows some interchange of experimental results (Karpinka et al. 2015).

Moreover, Xenopus tadpole stages are able to regenerate many tissues and organs, including the spinal cord, lens, tail, and limbs; this ability decreases through metamorphosis progression and is almost completely lost after metamorphosis (Filoni et al. 1995, 1997; Slack et al. 2004; Gaete et al. 2012). This transition offers the ability to compare the responses to damage in regenerative versus nonregenerative stages, in order to untangle the mechanisms responsible for regeneration competence (Gaete et al. 2012; Lee-Liu et al. 2014, 2018; Muñoz et al. 2015). Furthermore, functional recovery can be evaluated through simple behavioral tests: Classification of swimming behavior (Gaete et al. 2012) and measurement of free swimming distances (Muñoz et al. 2015; Edwards-Faret et al. 2017) can be used for spinal cord and tail regeneration evaluation, and optomotor response or visual avoidance behavior can be used for visual system regeneration assessment (McKeown et al. 2013). This positions Xenopus as a good model organism for performing preclinical trials. 
Even though some specific antibodies and reagents are still lacking, the Xenopus community has an established database resource, Xenbase (www.xenbase.org), that works as a repository for information about the genome, genes, expression profiles, gene function, and useful reagents and biological data obtained from Xenopus research (James-Zorn et al. 2015). Likewise, there are community resources, such as the National Xenopus Resource (Marine Biological Laboratory), the European Xenopus Resource Centre (University of Portsmouth), the Biological Resource Center Xenopus (University of Rennes 1), and the National BioResource Project (Hiroshima University), that rear and distribute transgenic lines.

\section{EXPERIMENTAL SYSTEMS FOR THE STUDY OF WOUND HEALING AND REGENERATION IN XENOPUS}

Regeneration can be addressed at many levels: (1) epimorphic regeneration, involving the formation of a blastema that guides the regeneration of a complex structure (e.g., limb regeneration); (2) tissue regeneration, considering regeneration without blastema formation (i.e., spinal cord, lens, and embryonic regeneration); (3) cellular regeneration, which encompasses reconstruction of a damaged cell (e.g., axon regeneration); and (4) wound healing, implying scar-free or scar-based repair of a tissue (e.g., epidermis) (Carlson 2007). Here we provide an overview of some of the latest Xenopus experimental approaches that allow the study of regeneration at different levels (Fig. 1), many of which are described in detail in the accompanying protocols.

Limb regeneration capacities have been studied during development (Komala 1957; Suzuki et al. 2006; Keenan and Beck 2016); nonetheless, what hinders these studies is variation in the degree of regeneration among tadpoles. For decreasing this variation, special attention should be given to larval maintenance as well as to precision and consistency of limb amputation; see Protocol: Studies of Limb Regeneration in Larval Xenopus (Fig. 1, Limb amputation; Mescher and Neff 2019). As limb regeneration involves different tissues, it is a great model for studying the effect of different compounds on successful regeneration and patterning of these tissues (King et al. 2012; Mescher et al. 2013).

The inability of mammals to regenerate spinal cord is determined by cellular intrinsic and extrinsic factors (Kaplan et al. 2015). On one hand, mammalian spinal cord axons are able to grow in a regenerative permissive environment (Richardson et al. 1980; David and Aguayo 1981), providing evidence that extrinsic factors, present in the spinal cord environment, restrict or favor axon regeneration. On the other hand, stem cells, grafted into an injured mammalian spinal cord, are able to differentiate into neurons despite the nonpermissive environment ( $\mathrm{Lu}$ et al. 2012), proving that there are some intrinsic factors, within the neurons, hampering spinal cord regeneration in mammals. Even though specific protocols for generating different types of spinal cord injuries, including their pros and cons, have been published (Polezhaev and Carlson 1972; Lee-Liu et al. 2013; Edwards-Faret et al. 2017; Phipps et al. 2020), they cannot discriminate between intrinsic and extrinsic factors. Transplantation experiments, involving regenerative stages as donors and nonregenerative stages as hosts, allow one to study intrinsic factors of regenerative cells in a nonregenerative environment (Méndez-Olivos et al. 2017). Cell transplantation experiments can be performed in the spinal cord; see Protocol: Cell Transplantation as a Method to Investigate Spinal Cord Regeneration in Regenerative and Nonregenerative Xenopus Stages (Fig. 1, Transplant; Méndez-Olivos and Larraín 2018).

Stages of lens regeneration are well-characterized (Freeman 1963; Henry 2003; Henry and Tsonis 2010). In Xenopus, different stages of lens regeneration can be studied in whole animals after lentectomy; see Protocol: Methods for Examining Lens Regeneration in Xenopus (Fig. 1, Lentectomy; Henry et al. 2019b). In addition, one can prepare ex vivo eye tissue cultures to examine specific eye tissue interactions; see Protocol: Ex Vivo Eye Tissue Culture Methods for Xenopus (Fig. 1, Ex vivo eye culture; Henry et al. 2019a).

Finally, to understand the involvement of specific genes, proteins, or signaling pathways in wound healing, oocytes and embryos can be studied. If a quick assay is needed, mechanical wounding can be performed. If greater consistency of wounding is needed or if the interest is on studying the early steps 
P.G. Slater et al.

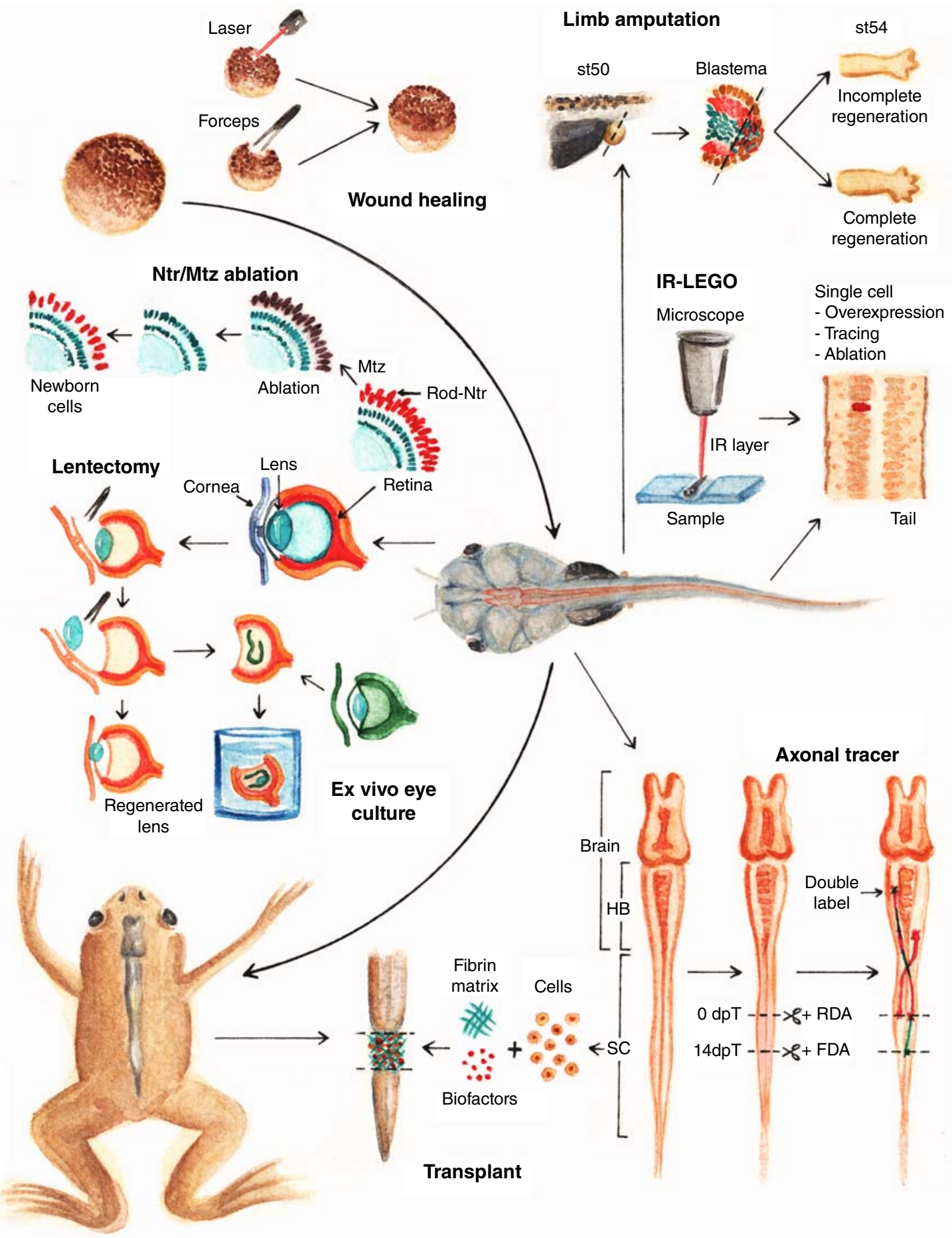

FIGURE 1. Experimental approaches and methods for studying wound healing and regeneration in Xenopus. Shown are some of the Xenopus life cycle stages and methods (introduced in the text) that are used to study different phenomena: oocytes for wound healing, tadpoles for limb and lens regeneration, and tadpoles in combination with froglets for transplantation studies.

or the dynamics of wound healing, laser wounding is preferred. The involvement of different signaling pathways in wound healing can be achieved by using glutathione-S-transferase (GST) pull-down assays of signaling molecules. See Protocol: Investigating the Cellular and Molecular Mechanisms of Wound Healing in Xenopus Oocytes and Embryos (Fig. 1, Wound healing; Li and Amaya 2019). 


\section{CELLULAR AND MOLECULAR METHODS FOR THE STUDY OF REGENERATION MECHANISMS}

Many groups have shed light on the mechanisms involved in regeneration (for reviews, see Lee-Liu et al. 2017; Phipps et al. 2020). These include cellular migration (Yoshii et al. 2007; Aztekin et al. 2019), proliferation and differentiation (Yoshino and Tochinai 2004; Gaete et al. 2012; McKeown et al. 2013; Muñoz et al. 2015), and inflammation and the immune response (Mescher et al. 2017), among others.

Considering the cases of tail, spinal cord, limb, and retina injury, the regeneration of nerve connections is crucial (Gaze 1959; Filoni and Paglialunga 1990; Zhao and Szaro 1994; Taniguchi et al. 2008). Thus, relevant questions arise: Which neuronal connections are recovered? Which neuronal nuclei are involved in the regenerative process? Are the axons regenerating and regrowing (e.g., sprouting), or are new neurons being generated? These questions can be addressed by using double axonal tracing in an injured spinal cord; see Protocol: Tracing Central Nervous System Axon Regeneration in Xenopus (Fig. 1, Axonal tracer; Gibbs and Szaro 2018). This sequential retrograde double-labeling approach uses dextran amines that are incorporated only in terminals or cut axons, allowing the labeling of regenerated axons.

Additionally, understanding the contribution of specific cell types on cell death, proliferation, and regeneration is another recurring question in the regeneration field. This can be addressed through cellular ablation, and the specificity of the observation relies on precise spatial and temporal control of the ablation of a specific cell type. The nitroreductase/metronidazole (NTR/Mtz) system addresses these requirements; see Protocol: Rod-Specific Ablation Using the Nitroreductase/Metronidazole System to Investigate Regeneration in Xenopus (Fig. 1, Ntr/Mtz ablation; Martinez-De Luna and Zuber 2018). The NTR/Mtz system expresses NTR under the control of a cell-type-specific promoter, and, following treatment with Mtz, a cytotoxic product is generated in the NTR-expressing cells, resulting in cell death.

Finally, if the interest focuses on single cells or a cluster of cells for determining (1) the cell fate of a specific cell, (2) the role of a particular gene in a specific cell, or (3) the role of a particular cell during the spinal cord regeneration process, the infrared laser-evoked gene operator (IR-LEGO) system can be used; see Protocol: Infrared Laser-Mediated Gene Induction at the Single-Cell Level in the Regenerating Tail of Xenopus laevis Tadpoles (Fig. 1, IR-LEGO; Hasugata et al. 2018). IR-LEGO allows gene induction at the single-cell level by generating local heat shock by laser irradiation or ablation of a specific cell by using higher-laser-power irradiation. The IR-LEGO system is highly robust and generates focused cellular damage (Kamei et al. 2009).

In summary, Xenopus is clearly an outstanding model organism to study wound healing and regeneration, and the Xenopus community has constantly been developing approaches and methods to improve research in this area. Continued advances in understanding regenerative mechanisms in Xenopus may provide novel insights to improve regeneration in humans.

\section{COMPETING INTEREST STATEMENT}

The authors declare no conflicts of interest.

Our work is supported by FONDECYT 1180429 (for J.L.) and 3190820 (for P.G.S.) Figure 1 was created by@mimipalacios_art. 


\section{REFERENCES}

Amin NM, Tandon P, Osborne Nishimura E, Conlon FL. 2014. RNA-seq in the tetraploid Xenopus laevis enables genome-wide insight in a classic developmental biology model organism. Methods 66: 398-409. doi:10 $.1016 /$ j.ymeth.2013.06.009

Azevedo AS, Grotek B, Jacinto A, Weidinger G, Saude L. 2011. The regenerative capacity of the zebrafish caudal fin is not affected by repeated amputations. PLoS One 6: e22820. doi:10.1371/journal .pone. 0022820

Aztekin C, Hiscock T, Marioni J, Gurdon J, Simons B, Jullien J. 2019. Identification of a regeneration-organizing cell in the Xenopus tail. Science 364: 653-658. doi:10.1126/science.aav9996

Bestman JE, Ewald RC, Chiu S-L, Cline HT. 2006. In vivo single-cell electroporation for transfer of DNA and macromolecules. Nat Protoc 1: 1267. doi:10.1038/nprot.2006.186

Blum M, De Robertis EM, Wallingford JB, Niehrs C. 2015. Morpholinos: antisense and sensibility. Dev Cell 35: 145-149. doi:10.1016/j.devcel .2015.09.017

Brant JO, Boatwright JL, Davenport R, Sandoval AGW, Maden M, Barbazuk WB. 2019. Comparative transcriptomic analysis of dermal wound healing reveals de novo skeletal muscle regeneration in Acomys cahirinus. PLoS One 14: e0216228. doi:10.1371/journal.pone .0216228

Carlson B. 2007. Principles of regenerative biology, 1st ed, pp. 1-23. Academic, San Diego.

Cline HT, Kelly D. 2012. Xenopus as an experimental system for developmental neuroscience: introduction to a special issue. Dev Neurobiol 72: 463-464. doi:10.1002/dneu.22012

Collart C, Owens ND, Bhaw-Rosun L, Cooper B, De Domenico E, Patrushev I, Sesay AK, Smith JN, Smith JC, Gilchrist MJ. 2014. High-resolution analysis of gene activity during the Xenopus mid-blastula transition. Development 141: 1927-1939. doi:10.1242/dev.102012

David S, Aguayo AJ. 1981. Axonal elongation into peripheral nervous system "bridges" after central nervous system injury in adult rats. Science 214: 931-933. doi:10.1126/science.6171034

Edwards-Faret G, Muñoz R, Méndez-Olivos EE, Lee-Liu D, Tapia VS, Larraín J. 2017. Spinal cord regeneration in Xenopus laevis. Nat Protoc 12: 372-389. doi:10.1038/nprot.2016.177

Eide FF, Eisenberg SR, Sanders TA. 2000. Electroporation-mediated gene transfer in free-swimming embryonic Xenopus laevis. FEBS Lett 486: 29-32. doi:10.1016/S0014-5793(00)02124-4

Farah Z, Fan H, Liu Z, He JQ. 2016. A concise review of common animal models for the study of limb regeneration. Organogenesis 12: 109-118. doi:10.1080/15476278.2016.1205775

Filoni S, Paglialunga L. 1990. Effect of denervation on hindlimb regeneration in Xenopus laevis larvae. Differentiation 43: 10-19. doi:10.1111/j.14320436.1990.tb00425.x

Filoni S, Bernardini S, Cannata SM. 1995. Differences in the decrease in regenerative capacity of various brain regions of Xenopus laevis are related to differences in the undifferentiated cell populations. J Hirnforsch 36: 523-529.

Filoni S, Bernardini S, Cannata SM, D’Alessio A. 1997. Lens regeneration in larval Xenopus laevis: experimental analysis of the decline in the regenerative capacity during development. Dev Biol 187: 13-24. doi:10.1006/ dbio. 1997.8598

Freeman G. 1963. Lens regeneration from the cornea in Xenopus laevis. J Exp Zool 154: 39-65. doi:10.1002/jez.1401540105

Gaete M, Muñoz R, Sánchez N, Tampe R, Moreno M, Contreras EG, Lee-Liu D, Larraín J. 2012. Spinal cord regeneration in Xenopus tadpoles proceeds through activation of Sox2-positive cells. Neural Dev 7: 13. doi:10 1186/1749-8104-7-13

Gawriluk TR, Simkin J, Thompson KL, Biswas SK, Clare-Salzler Z, Kimani JM, Kiama SG, Smith JJ, Ezenwa VO, Seifert AW. 2016. Comparative analysis of ear-hole closure identifies epimorphic regeneration as a discrete trait in mammals. Nat Commun 7: 11164. doi:10.1038/ ncomms 11164

Gawriluk TR, Simkin J, Hacker CK, Kimani JM, Kiama SG, Ezenwa VO, Seifert AW. 2019. Mammalian musculoskeletal regeneration is associated with reduced inflammatory cytokines and an influx of $\mathrm{T}$ cells. bioRxiv doi:10.1101/723783
Gaze R. 1959. Regeneration of the optic nerve in Xenopus laevis. Q J Exp Physiol Cogn Med Sci 44: 290-308.

Gerber T, Murawala P, Knapp D, Masselink W, Schuez M, Hermann S, GacSantel M, Nowoshilow S, Kageyama J, Khattak S, et al. 2018. Single-cell analysis uncovers convergence of cell identities during axolotl limb regeneration. Science 362: eaaq0681. doi:10.1126/science.aaq0681

Gibbs KM, Szaro BG. 2018. Tracing central nervous system axon regeneration in Xenopus. Cold Spring Harb Protoc doi:10.1101/pdb.prot101030

Gómez TM, Harrigan D, Henley J, Robles E. 2003. Working with Xenopus spinal neurons in live cell culture. Methods Cell Biol 71: 129-156. doi:10 .1016/S0091-679X(03)01008-2

Guo X, Zhang T, Hu Z, Zhang Y, Shi Z, Wang Q, Cui Y, Wang F, Zhao H, Chen Y. 2014. Efficient RNA/Cas9-mediated genome editing in Xenopus tropicalis. Development 141: 707-714. doi:10.1242/dev.099853

Harland RM, Grainger RM. 2011. Xenopus research: metamorphosed by genetics and genomics. Trends Genet 27: 507-515. doi:10.1016/j.tig .2011 .08 .003

Hasugata R, Hayashi S, Kawasumi-Kita A, Sakamoto J, Kamei Y, Yokoyama H. 2018. Infrared laser-mediated gene induction at the single-cell level in the regenerating tail of Xenopus laevis tadpoles. Cold Spring Harb Protoc doi: $10.1101 / \mathrm{pdb}$.prot101014

Haughton CL, Gawriluk TR, Seifert AW. 2016. The biology and husbandry of the African spiny mouse (Acomys cahirinus) and the research uses of a laboratory colony. J Am Assoc Lab Anim Sci 55: 9-17.

Hellsten U, Harland RM, Gilchrist MJ, Hendrix D, Jurka J, Kapitonov V, Ovcharenko I, Putnam NH, Shu S, Taher L. 2010. The genome of the Western clawed frog Xenopus tropicalis. Science 328: 633-636. doi:10 $.1126 /$ science. 1183670

Henry JJ. 2003. Cell and molecular biology of lens regeneration. Int Rev Cytol 228: 195-264. doi:10.1016/S0074-7696(03)28005-0

Henry JJ, Tsonis PA. 2010. Molecular and cellular aspects of amphibian lens regeneration. Prog Retin Eye Res 29: 543-555. doi:10.1016/j.preteyeres .2010 .07 .002

Henry JJ, Perry KJ, Hamilton PW. 2019a. Ex vivo eye tissue culture methods for Xenopus. Cold Spring Harb Protoc doi:10.1101/pdb.prot101535

Henry JJ, Perry KJ, Hamilton PW. 2019b. Methods for examining lens regeneration in Xenopus. Cold Spring Harb Protoc doi:10.1101/pdb .prot 101527

Ishibashi S, Kroll KL, Amaya E. 2008. A method for generating transgenic frog embryos. Methods Mol Biol 461: 447-466. doi:10.1007/978-160327-483-8_31

Itou J, Oishi I, Kawakami H, Glass TJ, Richter J, Johnson A, Lund TC, Kawakami Y. 2012. Migration of cardiomyocytes is essential for heart regeneration in zebrafish. Development 139: 4133-4142. doi:10.1242/dev.079756

James-Zorn C, Ponferrada VG, Burns KA, Fortriede JD, Lotay VS, Liu Y, Brad Karpinka J, Karimi K, Zorn AM, Vize PD. 2015. Xenbase: core features, data acquisition, and data processing. Genesis 53: 486-497. doi: $10.1002 / \operatorname{dvg} .22873$

Joven A, Simon A. 2018. Homeostatic and regenerative neurogenesis in salamanders. Prog Neurobiol 170: 81-98. doi:10.1016/j.pneurobio.2018.04.006

Joven A, Elewa A, Simon A. 2019. Model systems for regeneration: salamanders. Development 146: dev167700. doi:10.1242/dev.167700

Kamei Y, Suzuki M, Watanabe K, Fujimori K, Kawasaki T, Deguchi T, Yoneda Y, Todo T, Takagi S, Funatsu T. 2009. Infrared laser-mediated gene induction in targeted single cells in vivo. Nat Methods 6: 79-81. doi: $10.1038 /$ nmeth. 1278

Kaplan A, Ong Tone S, Fournier AE. 2015. Extrinsic and intrinsic regulation of axon regeneration at a crossroads. Front Mol Neurosci 8: 27. doi:10 $.3389 /$ fnmol.2015.00027

Karpinka JB, Fortriede JD, Burns KA, James-Zorn C, Ponferrada VG, Lee J, Karimi K, Zorn AM, Vize PD. 2015. Xenbase, the Xenopus model organism database; new virtualized system, data types and genomes. Nucleic Acids Res 43: D756-D763. doi:10.1093/nar/gku956

Keenan SR, Beck CW. 2016. Xenopus limb bud morphogenesis. Dev Dyn 245: 233-243. doi:10.1002/dvdy.24351

Ken-ichi TS, Isoyama Y, Kashiwagi K, Sakuma T, Ochiai H, Sakamoto N, Furuno N, Kashiwagi A, Yamamoto T. 2013. High efficiency TALENs enable F0 functional analysis by targeted gene disruption in Xenopus laevis embryos. Biol Open 2: 448-452. doi:10.1242/bio.20133855 
Khattak S, Murawala P, Andreas H, Kappert V, Schuez M, SandovalGuzman T, Crawford K, Tanaka EM. 2014. Optimized axolotl (Ambystoma mexicanum) husbandry, breeding, metamorphosis, transgenesis and tamoxifen-mediated recombination. Nat Protoc 9: 529-540. doi:10 $.1038 /$ nprot.2014.040

King MW, Neff AW, Mescher AL. 2012. The developing Xenopus limb as a model for studies on the balance between inflammation and regeneration. Anat Rec 295: 1552-1561. doi:10.1002/ar.22443

Komala Z. 1957. Comparative investigations on the course of ontogenesis and regeneration of the limbs in Xenopus laevis tadpoles in various stages of development. Folia Biol 5: 1-51.

Lee-Liu D, Edwards-Faret G, Tapia VS, Larraín J. 2013. Spinal cord regeneration: lessons for mammals from non-mammalian vertebrates. Genesis 51: 529-544. doi:10.1002/dvg.22406

Lee-Liu D, Moreno M, Almonacid LI, Tapia VS, Muñoz R, von Marées J, Gaete M, Melo F, Larraín J. 2014. Genome-wide expression profile of the response to spinal cord injury in Xenopus laevis reveals extensive differences between regenerative and non-regenerative stages. Neural Dev 9: 12. doi:10.1186/1749-8104-9-12

Lee-Liu D, Méndez-Olivos EE, Muñoz R, Larraín J. 2017. The African clawed frog Xenopus laevis: a model organism to study regeneration of the central nervous system. Neuroscience letters 652: 82-93. doi:10 .1016/j.neulet.2016.09.054

Lee-Liu D, Sun L, Dovichi NJ, Larraín J. 2018. Quantitative proteomics after spinal cord injury (SCI) in a regenerative and a nonregenerative stage in the frog Xenopus laevis. Mol Cell Proteomics 17: 592-606. doi:10.1074/ mcp.RA117.000215

Li J, Amaya E. 2019. Investigating the cellular and molecular mechanisms of wound healing in Xenopus oocytes and embryos. Cold Spring Harb Protoc doi:10.1101/pdb.prot100982

Lu P, Wang Y, Graham L, McHale K, Gao M, Wu D, Brock J, Blesch A, Rosenzweig ES, Havton LA. 2012. Long-distance growth and connectivity of neural stem cells after severe spinal cord injury. Cell 150: 1264-1273. doi:10.1016/j.cell.2012.08.020

Maden M, Varholick JA. 2020. Model systems for regeneration: the spiny mouse, Acomys cahirinus. Development 147: dev167718. doi:10.1242/ dev. 167718

Marques IJ, Lupi E, Mercader N. 2019. Model systems for regeneration: zebrafish. Development 146: dev167692. doi:10.1242/dev.167692

Martinez-De Luna RI, Zuber ME. 2018. Rod-specific ablation using the nitroreductase/metronidazole system to investigate regeneration in Xenopus. Cold Spring Harb Protoc doi:10.1101/pdb.prot100974

McKeown CR, Sharma P, Sharipov HE, Shen W, Cline HT. 2013. Neurogenesis is required for behavioral recovery after injury in the visual system of Xenopus laevis. J Comp Neurol 521: 2262-2278. doi:10 $.1002 / \mathrm{cne} .23283$

Méndez-Olivos EE, Larraín J. 2018. Cell transplantation as a method to investigate spinal cord regeneration in regenerative and nonregenerative Xenopus stages. Cold Spring Harb Protoc doi:10.1101/pdb.prot101006

Méndez-Olivos EE, Muñoz R, Larraín J. 2017. Spinal cord cells from premetamorphic stages differentiate into neurons and promote axon growth and regeneration after transplantation into the injured spinal cord of non-regenerative Xenopus laevis froglets. Front Cell Neurosci 11: 398. doi:10.3389/fncel.2017.00398

Mescher AL, Neff AW. 2019. Studies of limb regeneration in larval Xenopus. Cold Spring Harb Protoc doi:10.1101/pdb.prot100990

Mescher AL, Neff AW, King MW. 2013. Changes in the inflammatory response to injury and its resolution during the loss of regenerative capacity in developing Xenopus limbs. PLoS One 8: e80477. doi:10.1371/ journal.pone.0080477

Mescher AL, Neff AW, King MW. 2017. Inflammation and immunity in organ regeneration. Dev Comp Immunol 66: 98-110. doi:10.1016/j.dci .2016 .02 .015

Muñoz R, Edwards-Faret G, Moreno M, Zuñiga N, Cline H, Larraín J. 2015. Regeneration of Xenopus laevis spinal cord requires Sox $2 / 3$ expressing cells. Dev Biol 408: 229-243. doi:10.1016/j.ydbio.2015.03.009
Nakajima K, Yaoita Y. 2015. Highly efficient gene knockout by injection of TALEN mRNAs into oocytes and host transfer in Xenopus laevis. Biology Open 4: 180-185. doi:10.1242/bio.201410009

Nowoshilow S, Schloissnig S, Fei JF, Dahl A, Pang AWC, Pippel M, Winkler S, Hastie AR, Young G, Roscito JG, et al. 2018. The axolotl genome and the evolution of key tissue formation regulators. Nature 554: 50-55. doi:10.1038/nature25458

Peshkin L, Wuhr M, Pearl E, Haas W, Freeman RM Jr, Gerhart JC, Klein AM, Horb M, Gygi SP, Kirschner MW. 2015. On the relationship of protein and mRNA dynamics in vertebrate embryonic development. Dev Cell 35: 383-394. doi:10.1016/i.devcel.2015.10.010

Phipps LS, Marshall L, Dorey K, Amaya E. 2020. Model systems for regeneration: Xenopus. Development 147: $\operatorname{dev} 180844$. doi:10.1242/dev .180844

Polezhaev LV, Carlson BM. 1972. Loss and restoration of regenerative capacity in tissues and organs of animals. Harvard University Press, Boston.

Richardson P, McGuinness U, Aguayo A. 1980. Axons from CNS neurones regenerate into PNS grafts. Nature 284: 264-265. doi:10 $.1038 / 284264 \mathrm{a} 0$

Sakane Y, Sakuma T, Kashiwagi K, Kashiwagi A, Yamamoto T, Suzuki KT. 2014. Targeted mutagenesis of multiple and paralogous genes in Xenopus laevis using two pairs of transcription activator-like effector nucleases. Dev Growth Differ 56: 108-114. doi:10.1111/dgd .12105

Seifert AW, Kiama SG, Seifert MG, Goheen JR, Palmer TM, Maden M. 2012. Skin shedding and tissue regeneration in African spiny mice (Acomys). Nature 489: 561-565. doi:10.1038/nature11499

Session AM, Uno Y, Kwon T, Chapman JA, Toyoda A, Takahashi S, Fukui A, Hikosaka A, Suzuki A, Kondo M. 2016. Genome evolution in the allotetraploid frog Xenopus laevis. Nature 538: 336-343. doi:10.1038/ nature 19840

Sive H, Grainger R, Harland R. 2000. Early development of Xenopus laevis: a laboratory manual. Cold Spring Harbor Laboratory Press, Cold Spring Harbor, New York.

Slack J, Beck C, Gargioli C, Christen B. 2004. Cellular and molecular mechanisms of regeneration in Xenopus. Philos Trans R Soc Lond B Biol Sci 359: 745-751. doi:10.1098/rstb.2004.1463

Smith JJ, Timoshevskaya N, Timoshevskiy VA, Keinath MC, Hardy D, Voss SR. 2019. A chromosome-scale assembly of the axolotl genome. Genome Res 29: 317-324. doi:10.1101/gr.241901.118

Sun L, Bertke MM, Champion MM, Zhu G, Huber PW, Dovichi NJ. 2014. Quantitative proteomics of Xenopus laevis embryos: expression kinetics of nearly 4000 proteins during early development. Sci Rep 4: 4365. doi:10.1038/srep04365

Suzuki M, Yakushiji N, Nakada Y, Satoh A, Ide H, Tamura K. 2006. Limb regeneration in Xenopus laevis froglet. Sci World J 6: 26-37. doi:10.1100/ tsw. 2006.325

Taniguchi Y, Sugiura T, Tazaki A, Watanabe K, Mochii M. 2008. Spinal cord is required for proper regeneration of the tail in Xenopus tadpoles. Dev Growth Differ 50: 109-120. doi:10.1111/j.1440-169X 2007.00981.x

Varshney GK, Sood R, Burgess SM. 2015. Understanding and editing the zebrafish genome. Adv Genet 92: 1-52. doi:10.1016/bs.adgen.2015 .09 .002

Yoshii C, Ueda Y, Okamoto M, Araki M. 2007. Neural retinal regeneration in the anuran amphibian Xenopus laevis post-metamorphosis: transdifferentiation of retinal pigmented epithelium regenerates the neural retina. Dev Biol 303: 45-56. doi:10.1016/j.ydbio.2006.11.024

Yoshino J, Tochinai S. 2004. Successful reconstitution of the nonregenerating adult telencephalon by cell transplantation in Xenopus laevis. Dev Growth Differ 46: 523-534. doi:10.1111/j.1440-169x.2004 .00767.x

Zhao Y, Szaro BG. 1994. The return of phosphorylated and nonphosphorylated epitopes of neurofilament proteins to the regenerating optic nerve of Xenopus laevis. J Comp Neurol 343: 158-172. doi:10.1002/cne .903430112 


\section{Xenopus, a Model to Study Wound Healing and Regeneration: Experimental Approaches}

Paula G. Slater, Miriam Palacios and Juan Larraín

Cold Spring Harb Protoc; doi: 10.1101/pdb.top100966 originally published online March 29, 2021

\begin{tabular}{|c|c|}
\hline $\begin{array}{r}\text { Email Alerting } \\
\text { Service }\end{array}$ & Receive free email alerts when new articles cite this article - click here. \\
\hline $\begin{array}{r}\text { Subject } \\
\text { Categories }\end{array}$ & $\begin{array}{l}\text { Browse articles on similar topics from Cold Spring Harbor Protocols. } \\
\text { Cell Biology, general (1382 articles) } \\
\text { Developmental Biology (728 articles) } \\
\text { Neuroscience, general (357 articles) } \\
\text { Stem Cells (46 articles) } \\
\text { Stem Cells, general (70 articles) } \\
\text { Xenopus (210 articles) }\end{array}$ \\
\hline
\end{tabular}

